\title{
LEADERSHIP STYLES, TALENT RETENTION PRACTICES AND LABOR INVOLVEMENT IN THE TOURISM SECTOR OF THE BOYACÁ DEPARTMENT - COLOMBIA
}

\author{
LEYLA CAROLINA LÓPEZ ${ }^{1}$, OCTAVIO JOSÉ SALCEDO PARRA \& DANILO ALFONSO \\ SARMIENTO ${ }^{3}$ \\ ${ }^{I}$ Facultad de Ciencias de la Salud, Programa de Psicología, Universidad Pedagógica y Tecnológica de Colombia, \\ Tunja, Colombia \\ ${ }^{2,3}$ Facultad de Ingenierías, Universidad Distrital Francisco José de Caldas, Bogotá D.C., Colombia
}

\section{ABSTRACT}

This research analyzes models of leadership styles, talent retention strategies and levels of labor involvement in a sample of 54 hotels in the twelve provincial capitals of the department of Boyacá. Through extensive fieldwork in which 38 leaders and 63 employees participated, two MLQ-5X and Labor Involvement Scale instruments were applied and the leaders of each hotel were interviewed to know the degree of implementation of retention strategies. The results show that in both the responses of bosses and collaborators, the style of transformational leadership predominates, that only half of the leaders interviewed report having implemented retention strategies as a way of ensuring talent and that the levels of labor involvement of respondents are at medium and high levels. The research allows to expand the knowledge of the sector, deepens for the first time the study variables in this region and opens up new lines of research aimed at the development of a workforce committed to the success of tourism in Boyacá; It also socializes a prediction model of human talent retention capacity in a company in the tourism sector using intelligent models.

KEYWORDS: LSTM, Prediction, Tourism \& Travel

Received: Nov 01, 2020; Accepted: Nov 21, 2020; Published: Dec 04, 2020; Paper Id.: IJMPERDDEC20208

\section{INTRODUCTION}

Taking into account that the most important resource of any organization is constituted by people [1], it is important that companies that seek to remain competitive in their sector design strategies to retain human talent in order to maintain the ideal staff for achieve the objectives set. It is currently considered that human talent can lead organizations and therefore a country to be competitive worldwide [2]. Thus, proper management of human talent is an important part for the sustainable and sustainable growth of companies [3]. Tourism is one of the most important and dynamic sectors in the world, thanks to the generation of employment, the contribution of foreign exchange and its contribution to the regional development of countries, and therefore it is no stranger to the need to retain talent. In 2013, the sector generated about 194 million direct and indirect jobs around the world according to the estimates in the World Travel \& Tourism (2014).

The growth of the Colombian economy in recent years has been reflected in tourism-related activities. The Gross Domestic Product of hotel and restaurant services after mining, construction, financial services and transportation was one of the fastest growing sectors from 2010 to 2013 , which represented 0.7 percentage points above the national total. Foreign investment in the commerce, hotels and restaurants sector has also registered significant increases in recent years, especially in 2011 when investments registered a growth of 916\%. Tourism 
development leads to the creation of both qualified and unskilled jobs in both developed and developing countries [4]. According to the Departmental Strategic Plan of Science, Technology and Innovation of Boyacá by 2022, the department needs tourism, generate strategies to promote itself as a destination, promote the use of ICT, increase the training and linking of qualified talent to the sector and guarantee the care and preservation of the ecosystem.Since the hotel sector faces an environment with greater competitive pressures and its conditions of attraction and retention of talent are not entirely favorable, the role of managers and their management styles can help companies in the sector to use human resources available more effectively [5].

In this way, leadership as an organizational management process represents a fundamental element to guide the efforts and motivations of people towards the achievement of objectives. There is evidence that leadership styles based on charisma, personalized consideration, intellectual stimulation and idealized influence can positively influence job satisfaction and the permanence of the collaborator [6], [7], [8]. In the same way, there is evidence that the labor involvement of a person as a result of retention practices, can contribute to a greater interest in work and increase job satisfaction, which is a basic management principle of successful organizations [9]. Additionally, experiences show that greater labor involvement implies a transfer of commitment to tasks and that people or groups may be more willing to perform them [10]. Employees involved provide better service and this in turn can increase customer loyalty [11] and satisfied collaborators can maintain high performance and deliver quality services [12]. So since the hotel industry is a key sector in the social and economic development of our country for its contribution in the generation and redistribution of income and for its potential for the generation of new jobs, this research seeks to contribute to the understanding of styles leadership, the use of talent retention practices and the levels of labor involvement in the hotel sector in the Department of Boyacá with a view to facilitating the training and development of a competent workforce, motivated and committed to the success of tourism in the region.

\section{THEORETICAL FRAMEWORK}

\subsection{Leadership styles}

Leadership contributes significantly to the success or failure of an organization, which is why companies require effective managers who can guide their employees towards the fulfillment of goals and objectives [13]. Through an appropriate leadership style, managers can affect employee satisfaction, commitment and productivity, so the style can be seen as a series of attitudes, behaviors, characteristics and skills based on individual or group values, which allow the leader influences his followers to perform at their best [14]. The conceptual basis for the study of leadership styles arises from the perspectives of charismatic leadership and it is Burns in 1978 who introduces the distinction between transactional and transformational leaders. The former serve the interests of their followers, and the latter seek to raise the morale, motivation and values of their followers. Subsequently Bass in 1985 deepens the study of the styles identifies four dimensions for each one, elements that become the central axis of the research on leadership styles that sees the set of behaviors as a continuum and not as two separate categories [ 6].

\subsection{Talent retention practices}

The importance of human talent in the success of organizations of various kinds is well recognized in the literature [15], [16], [17], [18], [19]. The specific skills and competencies of the people who work in organizations are crucial for organizational competitiveness, an aspect that has been pointed out since the emergence of the theory of resources and 
capabilities [20]. The retention of human talent seeks to understand the reasons why employees make the decision to leave a company. In the literature it is found that in the sixties and seventies studies on this subject were intended to know the causes of why an employee decided to leave the organization [21], [22], [23] influencing negatively. However, it is until the 1990s, when explicitly, the phenomenon of retention begins to be investigated [24], [25].

\subsection{Labor involvement}

Some authors define the term involvement as the feeling of belonging and responsibility towards the organization [26]. It is also defined as the degree to which a person perceives their work [27]. Although it is not new, the concept of involvement is one of the most cited in the literature related to processes that improve the effectiveness of workers. [28] However, the idea of employee involvement in their work dates back to the 1950s [29]. According to [30], labor involvement develops when the worker has the power to act and make decisions thanks to the knowledge and experience that he acquired in the organization. The involvement has several characteristics that highlight its importance: impact on reducing absenteeism and staff turnover [31], improves work efficiency [32], increases the positive attitude towards work [33] and makes workers more committed to the tasks they perform. In general, the effects of involvement are: a) reduction of absenteeism; b) increase in performance levels; c) greater organizational effectiveness, and d) increased effort to fulfill tasks.

At present, organizations seek the active participation and involvement of workers as a way to improve productivity, understanding involvement as the worker's free and participatory process, where the total capacity of employees is used and is designed to encourage increasing commitment to the success of the organization [34].

\section{METHODOLOGY}

The research is a non-experimental cross-sectional design, because the data was collected at a single time and at a specific time and with the sole purpose of describing the variables. The treatment of the information is quantitative descriptive because the data were analyzed statistically and we sought to establish the frequencies in the variables studied in the chosen population.

\subsection{Participants}

The population for this study were workers belonging to the hotel sector of the twelve provincial capital cities of the Department of Boyacá: Tunja, Duitama, Sogamoso, Chiquinquirá, Villa de Leyva, Moniquirá, Ramiriquí, Garagoa, Guateque, Miraflores, Soatá and Chita. The selection of this sample was made in a non-probabilistic manner for convenience, and consisted of selecting the participants, who were accessible or available to respond to the instruments used. 101 workers participated, $70 \%$ of them women and 30\% men. 39\% are in a range between 18 and 25 years, $23 \%$ in a range between 26 and 35 years, 22\% between 36 and 45 years, 9\% in an age range between 46 and 55 years, and the remaining $8 \%$ are over 56 years old. As for schooling levels, 8\% of the participants have studies at the elementary level, $50 \%$ at the baccalaureate level, $21 \%$ at the technical level, $6 \%$ at the technology level, $15 \%$ at the level of professional careers and only $1 \%$ at the graduate level. It is found that of the participants who have post-baccalaureate training levels, $91 \%$ are trained in areas of knowledge not related to tourism or hospitality. $38 \%$ have a management role in the organization and the remaining $63 \%$ play support roles or customer service operation. Finally, the distribution of the 101 participants by city is shown in Table 1 . 
Table 1: Distribution in frequencies and percentages of the sample by cities

\begin{tabular}{|l|l|l|}
\hline \multicolumn{1}{|c|}{ City } & \multicolumn{1}{c|}{ N } & \multicolumn{1}{c|}{$\%$} \\
\hline Tunja & 27 & $26.7 \%$ \\
\hline Sogamoso & 16 & $15.8 \%$ \\
\hline Chiquinquirá & 11 & $10.9 \%$ \\
\hline Villa de Leyva & 11 & $10.9 \%$ \\
\hline Duitama & 7 & $6.9 \%$ \\
\hline Garagoa & 6 & $5.9 \%$ \\
\hline Miraflores & 6 & $5.9 \%$ \\
\hline Moniquirá & 5 & $5.0 \%$ \\
\hline Soatá & 5 & $5.0 \%$ \\
\hline Chita & 3 & $3.0 \%$ \\
\hline Ramiriquí & 3 & $3.0 \%$ \\
\hline Guateque & 1 & $1.0 \%$ \\
\hline
\end{tabular}

\subsection{Instruments}

For the measurement of leadership styles, the short version of the Multifactor Leadership Questionnaire (MLQ-5X) built by Bass and Avolio was used in 1977. This 45-item instrument on a five-point Likert scale and two referents (leader selfassessment and follower evaluation), describes behaviors and examines nine factors of the total range of the three leadership styles. The first five: idealized behavioral influence, attributed idealized influence, inspirational motivation, intellectual stimulation, individualized consideration describe the transformational style; the following three: contingent reward, address by active exception and address by passive exception describe the transactional style; and finally the latter is associated with the behaviors of absence of leadership and passive style or laizzes-faire style. The MLQ-5X is one of the few methodologies that has adequate psychometric properties both in internal consistency $(\alpha=0.63$ to 0.92 in the nine factors) and in convergent and discriminant validity [35]. In this version of the MLQ-5X, he also estimates three effects of the styles identified: extra effort, effectiveness and satisfaction Bass and Avolio in 1977. For the measurement of Labor Involvement, the adaptation of the Job Involvement Scale [36] by Andújar and Martínez-Lugo in 1996 was used. The scale consists of 20 items on a seven-point Likert scale and evaluates seven dimensions: negative character (items 10, 13, 18 and 19), concern for work (items 7, 9 and 20), proactivity (items 5, 6 and 12), sense of work (items 1, 2 and 3), importance of work (items 11 and 14), commitment (items 16 and 17) and the work flow factor (items 4, 8 and 15). This instrument has adequate validity and reliability $(\alpha=0.633)$ in Latin American samples as reported by [37]. In order to measure the implementation of retention practices by the leaders of the participating hotels, the question was used: has any personnel retention strategy been implemented? If the answer was affirmative, the type of practice implemented in relation to salary offer, induction / re-induction process, possibility of promotion / career and interest in family life was investigated

\subsection{Process.}

The procedure for applying the data collection methodology is described in the diagram shown in Figure 1. 
Analysis of the conceptual and practical foundations that support the justification of this study.

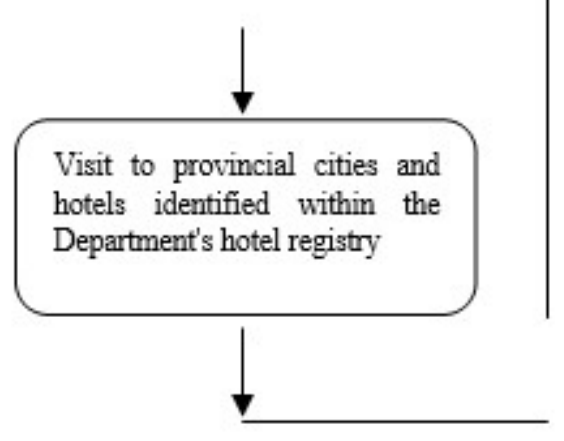

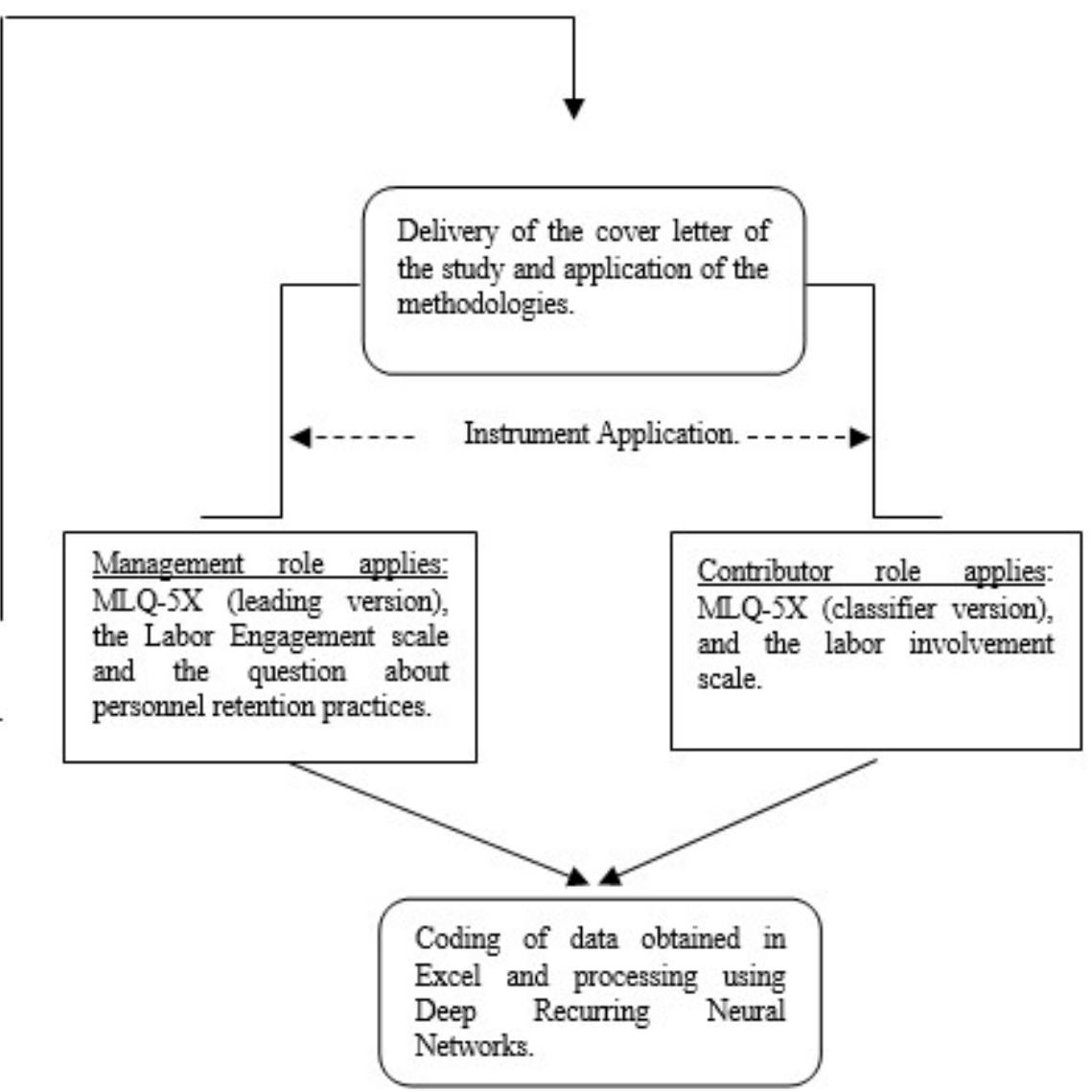

Figure 1: Procedure for data collection and information processing. Source: Authors

\section{RESULTS}

Referring to the reliability of the instruments used, Table 2 shows the means and standard deviations of the MLQ-5X, as well as the reliability calculated through the Cronbach alpha indicator. For the entire scale with the twelve elements, the value obtained was $\alpha=0.808$.

Table 2: Means, standard deviations and Cronbach's alpha of the MLQ-5X

\begin{tabular}{|l|l|l|l|}
\hline \multicolumn{1}{|c|}{ Dimensions } & \multicolumn{2}{c|}{ M } & DE \\
\hline Attributed Idealized Influence & 3,25 &, 767 &, 783 \\
\hline Behavioral Idealized Influence & 3,35 &, 713 &, 780 \\
\hline Inspirational Motivation & 3,62 &, 598 &, 793 \\
\hline Intellectual Stimulation & 3,25 &, 740 &, 784 \\
\hline Individualized Consideration & 3,23 &, 773 &, 783 \\
\hline Contingent Reward & 3,33 &, 750 &, 778 \\
\hline Active Exception Address & 2,68 &, 999 &, 811 \\
\hline Passive Exception Address & 1,15 &, 921 &, 830 \\
\hline Passive Leadership / Avoider & 1,59 &, 764 &, 820 \\
\hline Extra effort & 3,23 &, 870 &, 781 \\
\hline Effectiveness & 3,50 &, 730 &, 788 \\
\hline Satisfaction & 3,50 &, 757 &, 792 \\
\hline
\end{tabular}

Table 3 shows the values for the Labor Involvement scale. Cronbach's alpha value for the entire scale was 0.796. 
Table 3: Means, standard deviations and Cronbach's alpha of the Labor Involvement scale

\begin{tabular}{|l|l|l|l|}
\hline \multicolumn{1}{|c|}{ Dimensions } & \multicolumn{1}{c|}{ M } & \multicolumn{1}{c|}{ DE } & \multicolumn{1}{c|}{$\boldsymbol{\alpha}$} \\
\hline Negative character & 4,11 & 1,048 &, 745 \\
\hline Work Concern & 4,11 & 1,048 &, 745 \\
\hline Proactivity & 3,10 & 1,034 &, 764 \\
\hline Sense of Work & 3,98 &, 948 &, 781 \\
\hline Importance & 3,14 &, 906 &, 797 \\
\hline Commitment & 4,11 & 1,048 &, 745 \\
\hline Flow at Work & 3,85 &, 921 &, 800 \\
\hline
\end{tabular}

By checking that the values obtained in the scales that meet the recommended psychometric criteria of reliability and validity it is possible to continue with the analysis of the results of the variables studied.

Regarding leadership styles, Table 4 shows that hotel managers are mostly valued as transformational leaders $(76.3 \%)$. It is striking that none of the participants were placed in the category of passive leader.

Table 4: Leadership Styles from self-assessment referents

\begin{tabular}{|l|l|l|}
\hline \multicolumn{1}{|c|}{ Leadership Style Frequency } & \multicolumn{1}{c|}{ Leadership Style Frequency } & \multicolumn{1}{c|}{$\%$} \\
\hline Transformational Style & 29 & $76,3 \%$ \\
\hline Transactional Style & 9 & $23,7 \%$ \\
\hline Passive Style & 0 & $0,00 \%$ \\
\hline $\mathrm{N}=$ & 38 & $100,0 \%$ \\
\hline
\end{tabular}

When analyzing the styles from the perspective of the collaborators, a concordance between the distribution of the transformational and transactional styles is identified, and it is clear that none of the collaborators classify their boss within a passive style (see Table 5).

Table 5: Leadership styles from collaborator reference

\begin{tabular}{|l|l|l|}
\hline \multicolumn{1}{|c|}{ Leadership Style Frequency } & \multicolumn{1}{|c|}{ Leadership Style Frequency } & \multicolumn{1}{c|}{$\%$} \\
\hline Transformational Style & 45 & $71,4 \%$ \\
\hline Transactional Style & 18 & $28,5 \%$ \\
\hline Passive Style & 0 & $0,00 \%$ \\
\hline $\mathrm{N}=$ & 63 & $100,0 \%$ \\
\hline
\end{tabular}

When the responses of managers and collaborators are integrated and the responses are detailed for each of the twelve capitals (see Table 6), it is observed that the transformational style is prevalent in Duitama, Garagoa, Moniquirá, Chita and Ramiriquí, Tunja, Sogamoso and Chiquinquirá . In the cities of Villa de Leyva and Miraflores the distribution is more equal and only in Soatá does the transactional style prevail.

Table 6: Leadership styles by capital cities in the total sample

\begin{tabular}{|l|l|l|l|}
\hline \multicolumn{1}{|c|}{ City } & \multicolumn{1}{|c|}{ N } & Transformational Style & $\begin{array}{c}\text { Transactional } \\
\text { Style }\end{array}$ \\
\hline Tunja & 27 & 24 & 3 \\
\hline Sogamoso & 16 & 13 & 3 \\
\hline Chiquinquirá & 11 & 8 & 3 \\
\hline Villa Leyva & 11 & 7 & 4 \\
\hline
\end{tabular}




\begin{tabular}{|l|l|l|l|}
\hline Duitama & 7 & 7 & - \\
\hline Garagoa & 6 & 6 & - \\
\hline Miraflores & 6 & 4 & 2 \\
\hline Moniquirá & 5 & 5 & - \\
\hline Soatá & 5 & 1 & 4 \\
\hline Chita & 3 & 3 & - \\
\hline Ramiriquí & 3 & 3 & - \\
\hline Guateque & 1 & 1 & - \\
\hline N= & 101 & 82 & 19 \\
\hline
\end{tabular}

Regarding the implementation of retention practices as an element of organizational management, it is found that $50 \%$ of the managers surveyed affirm that they do not have such practices within their management strategy. Table 7 shows the number of managers by city and the orientation of the practice they report having implemented or used at some time.

Table 7: Implementation and type of personnel retention practices by city

\begin{tabular}{|l|l|l|l|l|l|l|}
\hline City & $\mathbf{N}$ & $\begin{array}{l}\text { Managers } \\
\text { Implement } \\
\text { Retention }\end{array}$ & Salary & $\begin{array}{l}\text { Induction- } \\
\text { reinduction }\end{array}$ & Advancement & $\begin{array}{l}\text { Family } \\
\text { Life }\end{array}$ \\
\hline Tunja & 9 & 2 & + & - & - & + \\
\hline Sogamoso & 3 & 3 & + & + & + & + \\
\hline Chiquinquirá & 4 & 2 & + & - & - & + \\
\hline Villa Leyva & 7 & 4 & + & + & + & + \\
\hline Duitama & 0 & 0 & - & - & - & - \\
\hline Garagoa & 5 & 2 & - & - & - & + \\
\hline Miraflores & 2 & 0 & - & - & - & - \\
\hline Moniquirá & 4 & 3 & + & - & + & + \\
\hline Soatá & 1 & 0 & - & - & - & - \\
\hline Chita & 1 & 1 & - & - & - & + \\
\hline Ramiriquí & 1 & 1 & + & - & + & + \\
\hline Guateque & 1 & 1 & - & - & + & + \\
\hline $\mathbf{N}=$ & $\mathbf{3 8}$ & $\mathbf{1 9}$ & & & \\
\hline
\end{tabular}

Regarding this variable, the analysis can be performed from two perspectives. The first from the level of implementation that for the conditions of the sector is very low and that coincides with that raised by [38] on the little importance given to this type of strategies within the sector at a global level. It also checks the findings in other latitudes in terms of working conditions, instability and high turnover. In capital cities such as Tunja, Miraflores, Garagoa and Villa de Leyva the implementation of strategies is very low among the participants. The second view focuses on the type of strategy used by those who answer affirmatively. The most used is the balance between work and family life, followed by the equitable salary with the market. Regarding the first strategy, there is no evidence of real consideration in the search for a balance between the two dimensions, and it can be attributed to the seasonality of the hiring that allows the worker to reconcile the roles. On the second, it shows that the managers of the surveyed hotels do not visualize the career development or permanent re-induction as a motivational factor that ensures the permanence of their employees. It is important that both investors and public and private promoters of the Department's tourism sector encourage the use of retention practices such as job enrichment, employee participation, job security and professional development as human management practices that focus on the long term but that ensure the permanence of the collaborator and can influence the 
commitment and levels of employee involvement of employees [38] and can improve the quality of service and productivity.

In relation to Labor Involvement, Table 8 shows that $73.2 \%$ of the participants, through their responses, report high levels of identification with their work and that 15.8 are in the middle level and $8.9 \%$ in the low level. It is important to note that none is located at the very low level offered by the scale. This allows us to initially interpret that people are mostly positively oriented towards their work and that there is adequate adherence to their labor role [39].

Table 8: Total Involvement Levels of the sample

\begin{tabular}{|l|l|l|}
\hline \multicolumn{1}{|c|}{$\begin{array}{c}\text { Levels Labor Involvement } \\
\text { Frequency }\end{array}$} & Frequency & \% \\
\hline Low & 9 & $8,9 \%$ \\
\hline Medium & 17 & $15,8 \%$ \\
\hline High & 73 & $73,2 \%$ \\
\hline Very high & 2 & $1,98 \%$ \\
\hline $\mathrm{N}=$ & 101 & 100,0 \\
\hline
\end{tabular}

The results as soon as this variable offers a favorable signal for talent management. As they point out [34], it is important that in the hotel sector there are workers who live processes of involvement in a natural way because this allows to achieve business success. As mentioned earlier, the involvement arises as the result of the connection of people from their interests and values with an object or situation. Thus this degree of identity can influence people's attitudes and behaviors and guide the intensity of behavior [40].

However, when analyzing the responses in each of the capitals (see Table 9), it can be seen that Moniquirá, Tunja, Sogamoso and Chiquinquirá have medium and low levels of involvement in an important proportion for their sample (between $33 \%$ and $60 \%$ )

Table 9: Engagement Styles by city - total of the sample

\begin{tabular}{|l|l|l|l|l|l|}
\hline \multicolumn{1}{|c|}{ City } & N & Low Level & Medium level & High Level & $\begin{array}{c}\text { Very High } \\
\text { Level }\end{array}$ \\
\hline Tunja & 27 & 2 & 5 & 20 & - \\
\hline Sogamoso & 16 & 2 & 3 & 10 & 1 \\
\hline Chiquinquirá & 11 & 1 & 5 & 5 & - \\
\hline Villa Leyva & 11 & - & - & 10 & 1 \\
\hline Duitama & 7 & 1 & - & 6 & - \\
\hline Garagoa & 6 & - & 1 & 5 & - \\
\hline Miraflores & 6 & - & - & 6 & - \\
\hline Moniquirá & 5 & 3 & - & 2 & - \\
\hline Soatá & 5 & - & 1 & 4 & - \\
\hline Chita & 3 & - & 1 & 2 & - \\
\hline Ramiriquí & 3 & - & - & 3 & - \\
\hline Guateque & 1 & - & - & 1 & - \\
\hline N= & 101 & 9 & 16 & 74 & 2 \\
\hline
\end{tabular}

These results generate a reflection on what was raised by [41] about the identification with the role of work in terms of central interest in life. It is possible to affirm that about $25 \%$ of the participants do not conceive their work as an 
important element in their life. The aforementioned authors emphasize that work activity is an important factor in the life of the individual and, therefore, an essential part of their identity. Therefore, the results raise a call to managers and promoters of the sector to design strategies to encourage work in this type of industry as an opportunity to consolidate a long-term career that integrates the concept that the person has of himself and his development as a member of a social group.

To close the analysis of the results, Table 10 integrates the three variables used for the present study. For each of the cities, the perceived leadership styles, the implementation of retention practices by the managers and the levels of involvement are observed in order to explore possible causal relationships between them in future investigations. In Tunja, although there is a prevalence of the transformational style that invites consideration and motivation of employees, the use of retention practices is very low with only $22.2 \%$. In the cases of Sogamoso, Chiquinquirá, Chita, Ramiriquí and Guateque, the results do suggest a possible relationship between the transformational style of managers and the implementation of retention practices. However, similar to the case of Tunja, the results in Soatá, Garagoa and Villa de Leyva the results do not suggest a relationship between the variables.

As for a possible relationship between the implementation of retention practices and levels of labor involvement, the results suggest a possible relationship in the cases of Sogamoso, Chita, Ramiriquí and Guateque whose leaders report using practices and levels of labor involvement are high. In the case of Tunja, the results suggest that low levels of involvement may be associated with the non-implementation of practices, but in turn they contradict each other because despite the low level in this variable the levels of involvement are high. In the cases of Garagoa, Miraflores and Soatá, despite not having retention practices, the levels of involvement are wide.

Then, although the indications that arise from the results of the present study, it may be important to continue contributing from the academy to the Department sector to provide solid empirical evidence that validates the possible relationships raised.

\section{PROTOTYPE FOR THE PREDICTION OF THE HUMAN TALENT RETENTION CAPACITY IN A TOURISM SECTOR COMPANY}

As a further product of this research, a software prototype based on artificial intelligence is socialized that allows predicting the ability to retain human talent of a company in the tourism sector based on leadership styles and levels of labor involvement of its workers.

This prototype can be used in populations with similar characteristics to those addressed in this research and is focused on the use of Long Short-Term Memory (LSTM).

\subsection{LSTM}

LSTMs (Figure 2) are a type of Recurrent Neural Network (RNN) used in the field of deep learning and used for time series prediction. 


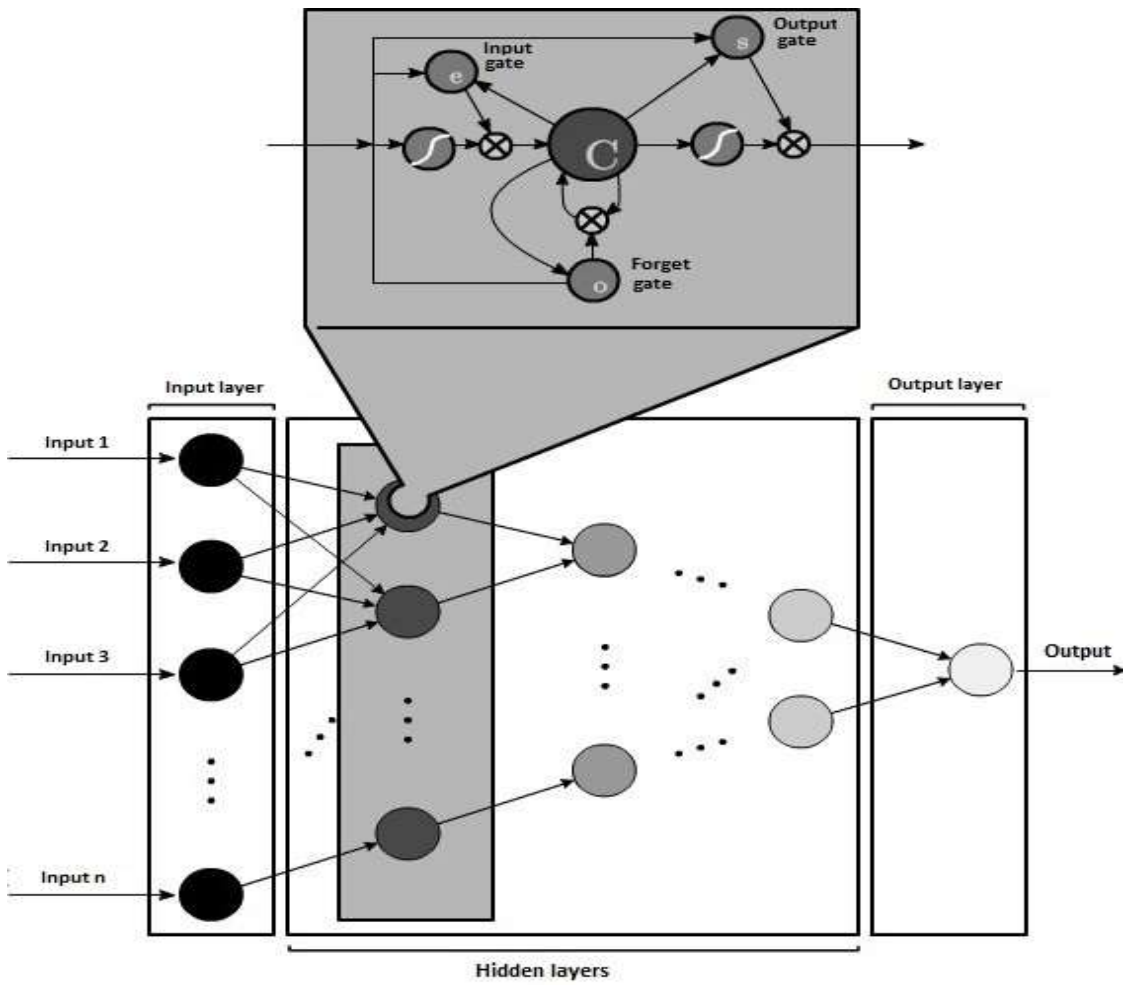

Figura 2: Representación gráfica de redes neuronales tipo LSTM. Source: Authors

Table 10: Leadership styles, labor involvement and staff retention practices in the total sample

\begin{tabular}{|c|c|c|c|c|c|c|c|c|c|}
\hline \multirow[b]{2}{*}{ City } & \multirow[b]{2}{*}{$\mathbf{N}$} & \multirow[b]{2}{*}{$\begin{array}{c}\text { Transformati } \\
\text { onal Style }\end{array}$} & \multirow[b]{2}{*}{$\begin{array}{c}\text { Transactio } \\
\text { nal Style }\end{array}$} & \multicolumn{2}{|c|}{$\begin{array}{l}\text { Personnel } \\
\text { Retention } \\
\end{array}$} & \multicolumn{4}{|c|}{ Labor Involviment } \\
\hline & & & & Yes & No & $\begin{array}{l}\text { Low } \\
\text { Level }\end{array}$ & $\begin{array}{l}\text { Mediu } \\
\text { m Lvel }\end{array}$ & $\begin{array}{l}\text { High } \\
\text { Level }\end{array}$ & $\begin{array}{l}\text { Very } \\
\text { High } \\
\text { Level }\end{array}$ \\
\hline Tunja & 27 & 24 & 3 & $\begin{array}{l}22,2 \\
\%\end{array}$ & $77,8 \%$ & 2 & 5 & 20 & - \\
\hline Sogamoso & 16 & 13 & 3 & $\begin{array}{l}100, \\
\%\end{array}$ & - & 2 & 3 & 10 & 1 \\
\hline $\begin{array}{l}\text { Chiquinqui } \\
\text { rá }\end{array}$ & 11 & 8 & 3 & $75, \%$ & $25 \%$ & 1 & 5 & 5 & - \\
\hline Villa Leyva & 11 & 7 & 4 & $\begin{array}{l}57,1 \\
\%\end{array}$ & $42,9 \%$ & - & - & 10 & 1 \\
\hline Duitama & 7 & 7 & - & - & - & 1 & - & 6 & - \\
\hline Garagoa & 6 & 6 & - & $40, \%$ & $60 \%$ & - & 1 & 5 & - \\
\hline Miraflores & 6 & 4 & 2 & - & $100 \%$ & - & - & 6 & - \\
\hline Moniquirá & 5 & 5 & - & $\begin{array}{l}50,0 \\
\%\end{array}$ & $50 \%$ & 3 & - & 2 & - \\
\hline Soatá & 5 & 1 & 4 & - & $100 \%$ & - & 1 & 4 & - \\
\hline Chita & 3 & 3 & - & $100 \%$ & - & - & 1 & 2 & - \\
\hline Ramiriquí & 3 & 3 & - & $100 \%$ & - & - & - & 3 & - \\
\hline Guateque & 1 & 1 & - & $100 \%$ & - & - & - & 1 & - \\
\hline $\mathrm{N}=$ & 101 & 82 & 19 & & & 9 & 16 & 74 & 2 \\
\hline
\end{tabular}

These types of structures (LSTM) can be explicitly designed to avoid the long-term dependency problem, remembering the information for long periods of time and learning new information in the present. LSTM blocks contain 
memory cells that allow you to remember a value for an arbitrary length of time and use it when necessary; It also has a forgetting layer that can erase the contents of the memory when it is not useful. All components are built for differentiable functions and trained during the backpropagation process [42]. The structure of an LSTM can be represented as shown in Figure 2, where the memory cell is symbolized by the letter $\mathrm{C}$, the forgotten layer by the letter $\mathrm{O}$, the input layer by the letter $\mathrm{E}$ and the output layer by the letter $\mathrm{S}$.

\subsection{Design of the operation of the LSTM prediction system [43]}

LSTM can be considered as a differentiable approximator of functions, which is usually trained with the descending gradient [44] and although a truncated form of the BPTT (Backpropagation Through Time) was originally used to approximate the gradient of [45], the investigation was done use of the calculation with BPTT without truncation based on the statements made by Graves in [46].

\subsubsection{Forward Pass equations}

For the input gate:

$a_{l}^{t}=\sum_{i=1}^{L} w_{i l}^{t} x_{i}^{t}+\sum_{h=1}^{H} w_{h l}^{t} b_{h}^{t-1}+\sum_{c=1}^{C} w_{c l} s_{c}^{t-1}+\theta_{l}(1)$

$b_{l}^{t}=f\left(a_{l}^{t}\right)(2)$

Fort the forget gate:

$a_{\emptyset}^{t}=\sum_{i=1}^{L} w_{i \emptyset}^{t} x_{i}^{t}+\sum_{h=1}^{H} w_{h \emptyset}^{t} b_{h}^{t-1}+\sum_{c=1}^{C} w_{c \emptyset} s_{c}^{t-1}+\theta_{\emptyset}(3)$

$b_{\varnothing}^{t}=f\left(a_{\varnothing}^{t}\right)(4)$

For the output gate:

$a_{w}^{t}=\sum_{i=1}^{L} w_{i w}^{t} x_{i}^{t}+\sum_{h=1}^{H} w_{h w}^{t} b_{h}^{t-1}+\sum_{c=1}^{C} w_{c w} s_{c}^{t-1}+\theta_{w}(5)$

$b_{w}^{t}=f\left(a_{w}^{t}\right)(6)$

The output of the $b_{c}^{t}$ neuron will indicate whether new learning was generated or stored information is retained. Having clear the above and starting from what is shown in Figure 3, it is concluded that the state and output of the cell are given by equations 7 to 9 [44].

Neuron status:

$a_{c}^{t}=\sum_{i=1}^{L} w_{i c}^{t} x_{i}^{t}+\sum_{h=1}^{H} w_{h c}^{t} b_{h}^{t-1}(7)$

$s_{c}^{t}=b_{\varnothing}^{t} s_{c}^{t-1}+b_{l}^{t} g\left(a_{c}^{t}\right)$

Neuron output:

$b_{c}^{t}=b_{w}^{t} h\left(s_{c}^{t}\right)(9)$ 


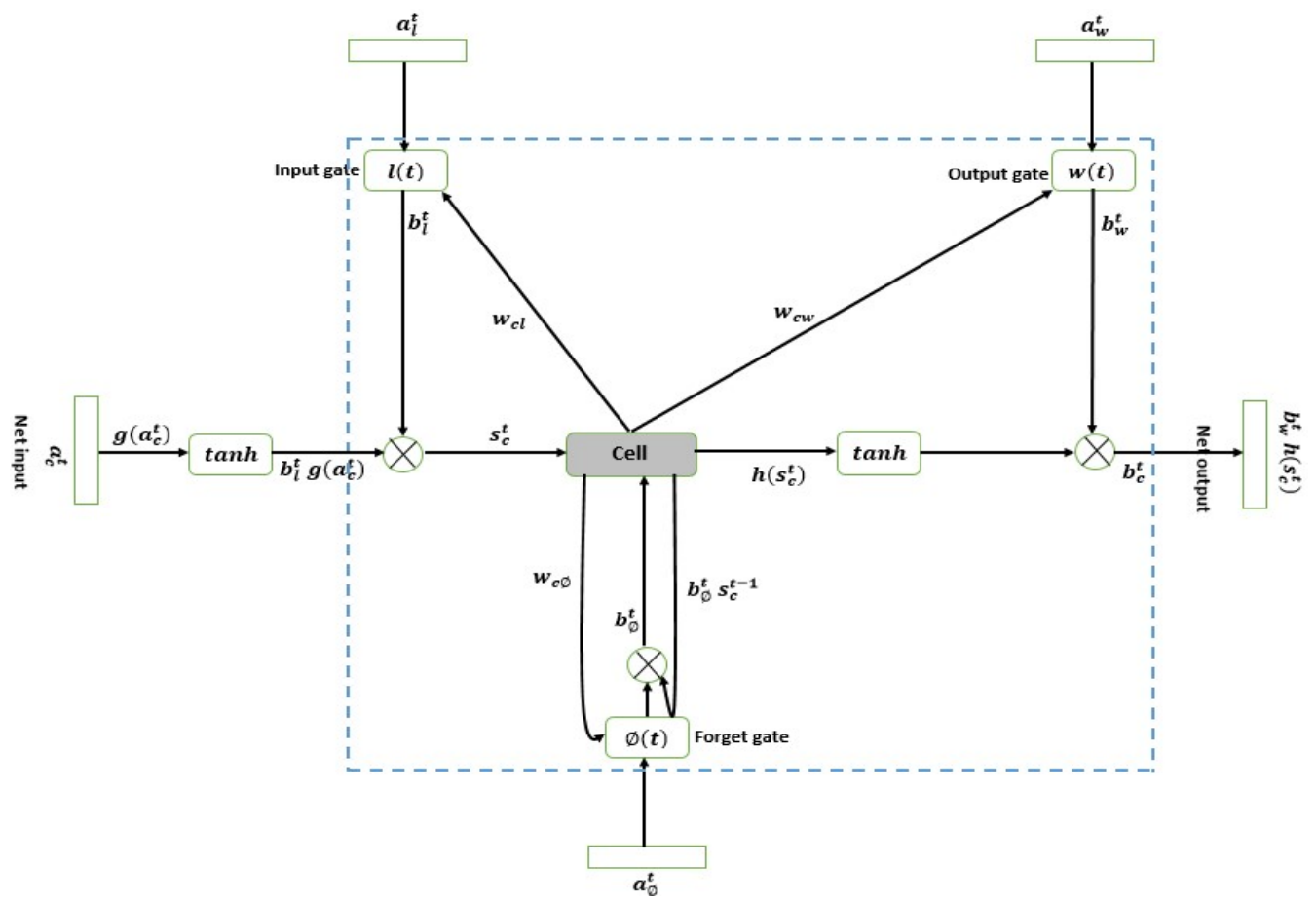

Figure 3. LSTM architecture used for the characterization of PUs. Source: Authors

\subsubsection{Equations Backward Pass}

To obtain the Backward Pass equations, the BPTT method is used (as mentioned above) [44] which implies the use of the chain rule to calculate the derivatives of the errors at the exit of the components of an LSTM block. Defining $E$ as the function of loss (error), and based on the fact that you want to establish how the error varies when making changes in weights, you have from the chain rule:

$$
\frac{\partial E}{\partial w_{i j}}=\frac{\partial E}{\partial a_{j}} \frac{\partial a_{j}}{\partial w_{i j}}=b_{i} \frac{\partial E}{\partial a_{j}}(10)
$$

From Equation 18, it's clear the goal is to calculate $\frac{\partial E}{\partial a_{j}}$, but taking into account that in the case of LSTM, 4 types of $a$ exist, namely $\left(\frac{\partial E}{\partial a_{w}^{t}}\right)$ output gate, $\left(\frac{\partial E}{\partial a_{c}^{t}}\right)$ cells, $\left(\frac{\partial E}{\partial a_{\emptyset}^{t}}\right)$ forget gate, and $\left(\frac{\partial E}{\partial a_{l}^{t}}\right)$ input gate, all of which can be defined as shown in Equations 11 to 14 .

$$
\begin{aligned}
\frac{\partial E}{\partial a_{w}^{t}} & =\sum_{c=1}^{C} \frac{\partial E}{\partial b_{c}^{t}} \frac{\partial b_{c}^{t}}{\partial b_{w}^{t}} \frac{\partial b_{w}^{t}}{\partial a_{w}^{t}}=\frac{\partial b_{w}^{t}}{\partial a_{w}^{t}} \sum_{c=1}^{C} \frac{\partial E}{\partial b_{c}^{t}} \frac{\partial b_{c}^{t}}{\partial b_{w}^{t}} \\
\frac{\partial E}{\partial a_{c}^{t}} & =\frac{\partial E}{\partial s_{c}^{t}} \frac{\partial s_{c}^{t}}{\partial a_{c}^{t}}(12) \\
\frac{\partial E}{\partial a_{\emptyset}^{t}} & =\sum_{c=1}^{C} \frac{\partial E}{\partial s_{c}^{t}} \frac{\partial s_{c}^{t}}{\partial b_{\emptyset}^{t}} \frac{\partial b_{\emptyset}^{t}}{\partial a_{\emptyset}^{t}}=\frac{\partial b_{\emptyset}^{t}}{\partial a_{\emptyset}^{t}} \sum_{c=1}^{C} \frac{\partial E}{\partial s_{c}^{t}} \frac{\partial s_{c}^{t}}{\partial b_{\emptyset}^{t}} \\
\frac{\partial E}{\partial a_{l}^{t}} & =\sum_{c=1}^{C} \frac{\partial E}{\partial s_{c}^{t}} \frac{\partial s_{c}^{t}}{\partial b_{l}^{t}} \frac{\partial b_{l}^{t}}{\partial a_{l}^{t}}=\frac{\partial b_{l}^{t}}{\partial a_{l}^{t}} \sum_{c=1}^{C} \frac{\partial E}{\partial s_{c}^{t}} \frac{\partial s_{c}^{t}}{\partial b_{l}^{t}}
\end{aligned}
$$


Taking into account that the summation is done over $c$ because the model is developed in a single block (with $C$ cells inside), the mathematical descriptions shown in Equation 15 are found when calculating the respective derivatives [44].

$$
\begin{gathered}
\frac{\partial s_{c}^{t}}{\partial b_{l}^{t}}=g\left(a_{c}^{t}\right) \frac{\partial s_{c}^{t}}{\partial b_{\varnothing}^{t}}=s_{c}^{t-1} \frac{\partial b_{c}^{t}}{\partial b_{w}^{t}}=h\left(s_{c}^{t}\right) \\
\frac{\partial b_{\varnothing}^{t}}{\partial a_{\varnothing}^{t}}=f^{\prime}\left(a_{\varnothing}^{t}\right) \frac{\partial s_{c}^{t}}{\partial a_{c}^{t}}=b_{l}^{t} g^{\prime}\left(a_{c}^{t}\right) \frac{\partial b_{l}^{t}}{\partial a_{l}^{t}}=f^{\prime}\left(a_{l}^{t}\right) \\
\frac{\partial b_{w}^{t}}{\partial a_{w}^{t}}=f^{\prime}\left(a_{w}^{t}\right)(15)
\end{gathered}
$$

Based on the mathematical analysis applied above, the following Backward Pass equations are obtained:

Output gate:

$\delta_{w}^{t}=\frac{\partial E}{\partial a_{w}^{t}}=f^{\prime}\left(a_{w}^{t}\right) \sum_{c=1}^{C} \epsilon_{c}^{t} h\left(s_{c}^{t}\right)$

Cell:

$\delta_{c}^{t}=\frac{\partial E}{\partial a_{c}^{t}}=\epsilon_{s}^{t} b_{l}^{t} g^{\prime}\left(a_{c}^{t}\right)$

Forget gate:

$\delta_{\varnothing}^{t}=\frac{\partial E}{\partial a_{\emptyset}^{t}}=f^{\prime}\left(a_{\varnothing}^{t}\right) \sum_{c=1}^{C} \epsilon_{s}^{t} s_{c}^{t-1}$

Input gate:

$\delta_{l}^{t}=\frac{\partial E}{\partial a_{l}^{t}}=f^{\prime}\left(a_{l}^{t}\right) \sum_{c=1}^{C} \epsilon_{s}^{t} g\left(a_{c}^{t}\right)$

\subsubsection{Flow chart of the LSTM system and test of the prediction model}

The flow chart for training (Figure 4). Begin your process by randomly initializing each neuron with values ranging from 1 to 1 .

Then, each training example is taken and the expected output is evaluated, if the response delivered does not correspond to the desired one, the algorithm calculates the error between the output obtained by the system and the expected one, correcting each weight of the gates (input, output, forget) and the cell through the application of weights and using tangential and sigmoid functions until culminating with all the training examples, and in this way approximating the output of the model to the expected one (by decreasing the error, as shown in section 5.2.2). 


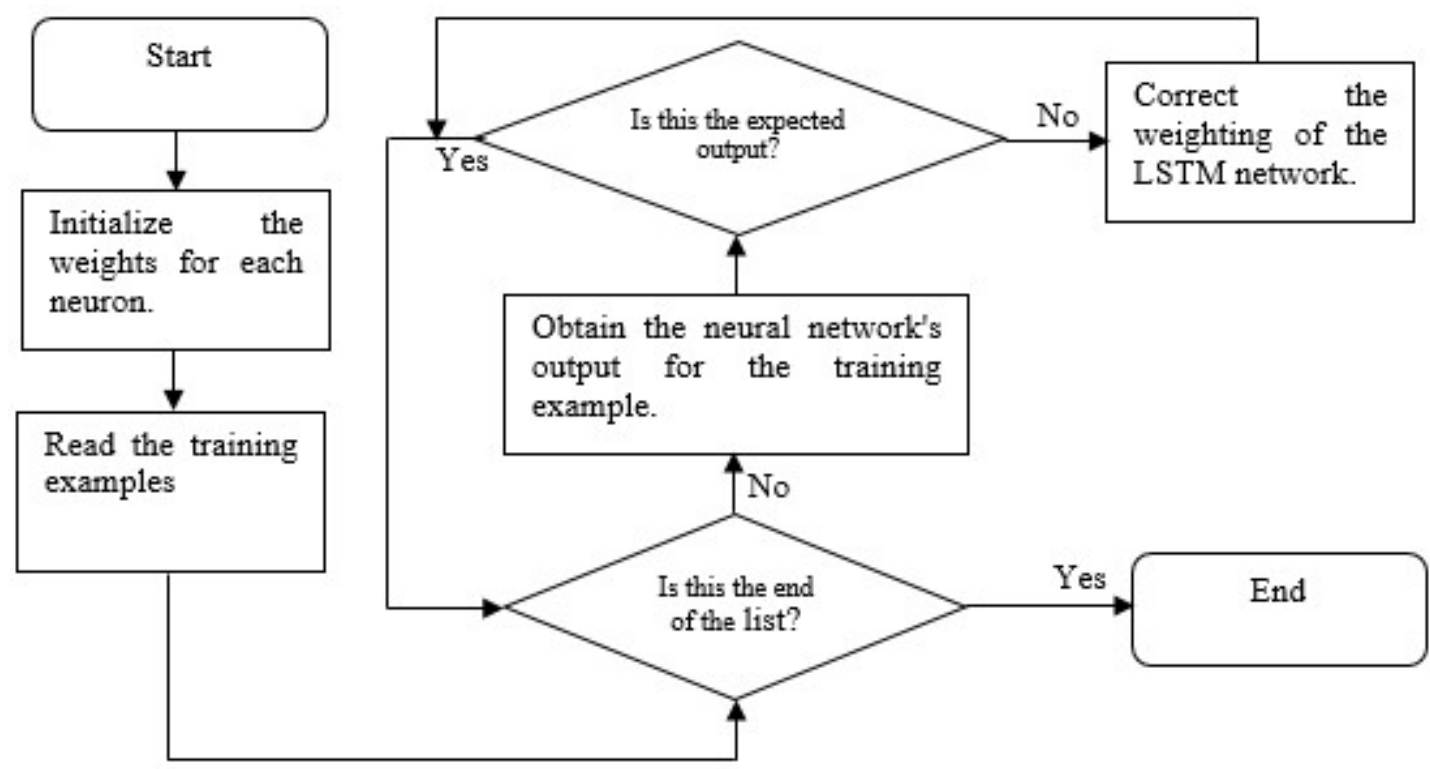

Figura 4: Diagrama de flujo de entrenamiento de la red LSTM para predicción de retención de talento en el sector turismo. Source: Authors

The results obtained when evaluating the model are shown in Figure 5. It is observed that there is a success in the prediction of up to $70 \%$, which indicates that the implementation of the LSTM could be used to make estimates in the area tour.

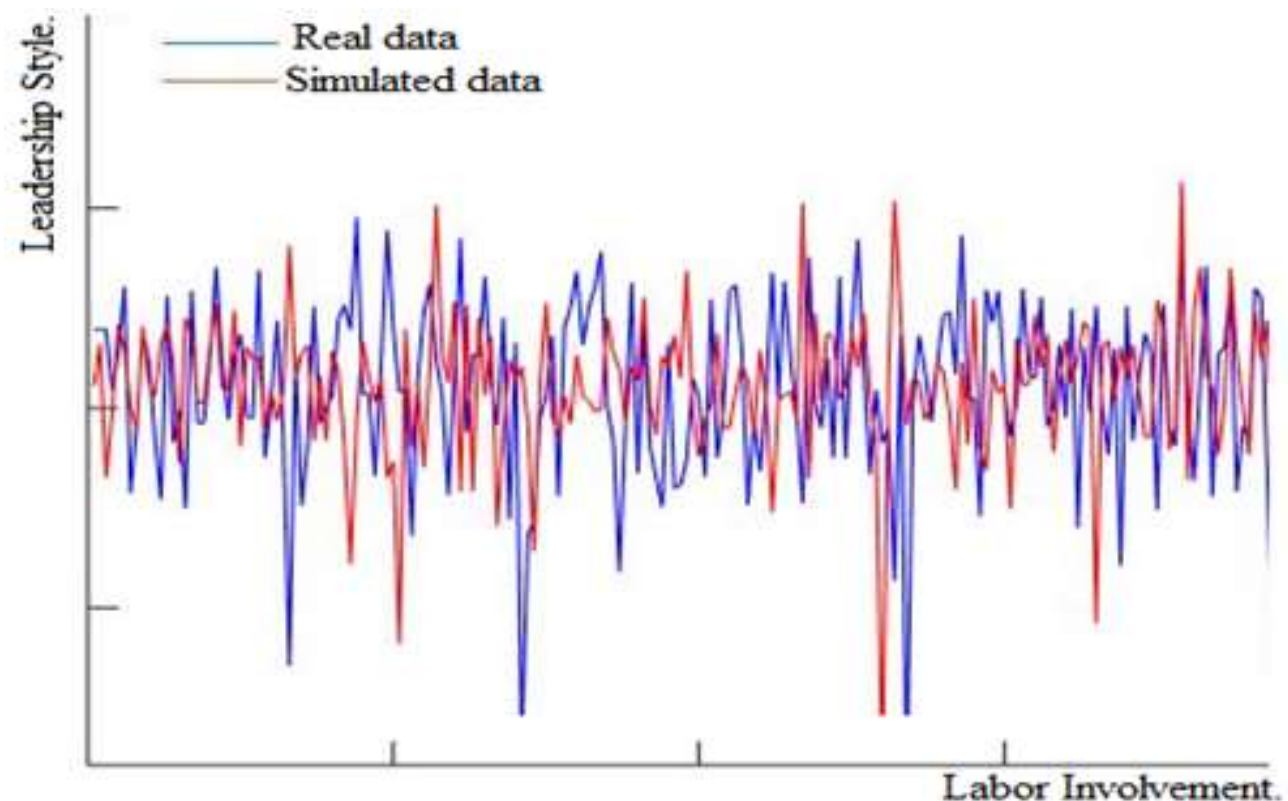

Figure 5: Estimation of human talent in the tourism sector (when the data entering the system has a chaotic behavior). Source: Authors

\section{DISCUSSIONS}

This research provides valuable information for public and private leaders and promoters of the sector, on the need to 
strengthen the variables described as key elements in achieving business objectives and as a basis for the design of training and development strategies for a force competent labor, motivated and committed to the success of tourism in the region.

Through extensive fieldwork that included the application of psychometric instruments and interviews, the study manages to identify leadership styles, the use of talent retention strategies and the levels of labor involvement that predominate in the tourism sector of the twelve provincial capitals of the Department of Boyacá.

When analyzing the results obtained in the application of the MLQ-5X multifactor leadership questionnaire, it is evident that the transformational leadership style is prevalent both in the self-evaluation by the leader, and in the evaluation carried out by the collaborators.

This allows us to propose that in the sample under study there are leaders with the ability to motivate their followers to achieve a performance that exceeds their own expectations and those of the organization as postulated [47]. Likewise and in accordance with what is stated by [48], the result is a positive element because this style of leadership is one of the most appropriate to induce change and innovation in organizations, inspires commitment to the organization and strengthens the effectiveness and motivation of the followers fundamental element in the purpose of reducing the intention of the employee to leave his job that is a recurring situation in this sector of the economy [49].

The style of transactional leadership is also present in the sample studied although not in a representative way, which allows to infer that some leaders prefer to motivate their collaborators under the idea of exchanging effort - reward and with pre-established benefits [50]. It is noted that no leader describes himself with a laissez-faire-passive style. However, a small number of collaborators consider that their leaders avoid facing various key situations for the management and refer through their responses that their leaders do not feed them properly and do not use rewards to encourage them, which can lead these people to feel dissatisfied, unproductive and with low levels of efficiency in their work [51].7.

\section{CONCLUSIONS}

As soon as the implementation of retention practices is found, half of the executives and leaders surveyed affirm that they have not yet implemented these types of practices within their company management strategy. This result shows the urgency for organizations in the hotel sector of the capitals of the province of Boyacá to implement strategies and talent retention plans. It is necessary that managers understand the importance of designing and implementing salary policies in line with the market, offer autonomy and control to people for the development of their functions, design routes and career plans that ensure professional growth, and that pay attention to the quality of life levels of their employees [52].

Regarding the results of labor involvement, it is found that participants refer in a high proportion, have a medium high and high level. This allows us to infer that workers in the sector (both leaders and collaborators) present an adequate psychology identification towards their work [39]. It is emphasized that, based on this high identification, the productivity levels of the sector can be strengthened through people's interest in making their capacities and abilities available to organizations and their genuine commitment to success [34]. As stated by [11] committed employees provide better service, and this in turn, can increase customer loyalty.

The research presents some methodological and practical limitations. The size of the sample and its low representativeness in some cities do not allow generalizations. This added to the high business informality found in the 
sector and the low interest of some people in front of the study made it difficult to obtain key information that would allow a deeper analysis of the information.

As an important variable, the research generated a software prototype based on LSN-type RNNs with the ability to predict the ability to retain human talent of a company in the tourism sector based on leadership styles and levels of labor involvement of its workers. This prototype must be adjusted in order to increase the percentage of estimation and may be used in populations with similar characteristics to those addressed in the present investigation.

Within the future lines of research, it is proposed to remedy the aforementioned limitations and propose a methodological design that allows establishing a causal relationship between the variables.

\section{ACKNOWLEDGMENTS}

The research developed is a continuation of the Master's degree work in Psychology "Estudios de liderazgo, prácticas de retención de talento e involucramiento laboral en el sector turístico del Departamento de Boyacá - Colombia" of the "Universidad de la Sabana". A very Special gratefulnes to Administrative Department of Science, Technology and Innovation (Colciencias), for financing the resources for the development of this research Project (ID: No. 733 - 2015).

\section{REFERENCES}

1. Münch, L. Administración de capital humano, la gestión del activo más valioso de la organización, 2005, México:

2. Caicedo-Valencia, V.M; Acosta-Aguirre, A.M. La gestión del talento humano y el ser humano como sujeto de desarrollo, Revista Politécnica, 8 (14), 105-113, 2012.

3. Baum, J.; Wally, S. Strategic decision speed and firm performance. Strategic Management Journal, 24, 1107-1129, 2003.

4. Dedu E. The relationship between tourism and employment in the tourism sector. Managerial challenges of the contemporary society.Babes Bolyai University, Cluj-Napoca, p. 121, 2012.

5. Kara, D. The Effects of managers' transformational leadership style on Employees organizational commitment. International Journal of Academic Research in Accounting, Finance and Management Sciences, 2(1), 16-25, 2013.

6. Bass, Bernard; Avolio, Bruce. Manual for the multifactor leadership questionnaire. Consulting Psychologist Press, Palo Alto. California. USA, 2006.

7. Velásquez, Luis. Habilidades Directivas y Técnicas de Liderazgo, Editorial Ideas Propias, España, 2006.

8. Lerma, Alejandro. Liderazgo emprendedor: cómo ser un emprendedor de éxito y no morir en el intento, Editorial Thompson, México, 2007.

9. Preuss, G. A; Lautsch, B. A. ABI/INFORM Global. [Online], retrieved: www.proquest.com, 517-541, 2012

10. Walsh, M; E., Milner. The potencial of employee involvement in an established Irish branch of multinational, Irish Journal of Management, 233, 2002.

11. Salanova, M; Agut, S; Peiro, J. M. Linking organizational resources and work engagement to employee performance and customer loyalty, The mediation of service climate, Journal of Applied Psychology, 90(6), 1217-1227, 2005.

12. Lalopa, J. M. Commitment and turnover in resort jobs. Journal of Hospitality and Tourism Research, 21(2), 11-16, 1997.

13. Lok, P; Crawford, J. The effect of organizational culture and leadership style on job satisfaction and organizational commitment: A cross-national comparison, Journal of Management Development, 23:321-338, 2003. 
14. Mosadeghrad, A.M. The role of participative management (suggestion system) in hospital effectiveness and efficiency, Research in Medical Sciences, 8(3), Isfahan, 85-9, 2003.

15. J Fabi, B; Raymond, L; Lacoursière, R. HRM practice clusters in relation to size and performance: An empirical investigation in Canadian manufacturing SMEs, Journal of Small Business and Entrepreneurship, 20(1), 25-40, 2007.

16. Hewitt, N. Resource and capability constraints to innovation in small and large plants. Small Business Economics, 26(3), 257277,2006

17. Laursen, K; Foss, N. New human resource management practices, complementarities and the impact on innovation performance, Cambridge Journal of Economics, 27(2), 243-263, 2003.

18. Michie, J; Sheehan, M. HRM practices, R\&D expenditure and innovative investment: Evidence from the UK's 1990 workplace industrial relations surveys (WIRS), Industrial and Corporate Change, 8(2), 211-234, 1999.

19. Vinding, A. Absorptive capacity and innovative performance: a human capital approach, Economics of Innovation and New Technology, 15(4/5), 507-517, 2006.

20. Barney, Jay B. Firm resources and sustained competitive advantage, Journal of Management, pp. 17, 99-120, 1991.

21. March, J. G; Simon, H. Organizations (Nueva York): John Wiley and Son, 1958.

22. Price, A. Human Resource Management in a Business Context. London: International Thompson Business Press, 1997.

23. Mobley, W. H. Employee Turnover: Causes, Consequences, and Control. Addison-Wesley Publishing, Philippines, 1982.

24. O'Reilly, C. A., \& Chatman, J. Organizational commitment and psychological attachment: The effects of compliance, identification, and internalization on prosocial behavior, Journal of Applied Psychology, 71(3), 492, 1986.

25. Meyer, J.P; Allen, N.J. A three component conceptualization of organizational commitment”, Human Resource Management Review, 1, pp. 61-98, 1991.

26. Mueller, C; Wallace J; Pricne J. Employee commiments: Resolving some issues, Work and ocupations, 210-240, 1992.

27. Ramsey, R; Lassk, F. G; Marshall, G. W. The Journal of Personal Selling and Sales Management. [Online], retrieved: www.proquest.com, 1995.

28. Lawler, E. I. High-involvement management: Participative strategies for improving organizational performance, Jossey-Bass, 1986.

29. Ciavarella, M. A. The adoption of high-involvement practices and processes in emergent and developing firms: a descriptive and prescriptive approach, Human resource Management, 2003.

30. Lawler III, E. Global talent management: Literature review, integrative framework, and suggestions for further research, Journal of World Business, 45, 122-133, 1999.

31. Warks, M. M. Employee participation in an quality circle program: impact on quality of work life, productivity and absenteesism. Journal of Applied Phycology, 1986.

32. Bush K; Spangle, R. The effects of quality circles on performance and promotions human Relations, 1990.

33. Steel, R. P; Lloyd, R. F. Cognitive, affective, and behavioral outcomes of participation in quality circles: Conceptual and empirical findings, Journal of Applied Behavioral Science, 24, 1-17, 1988.

34. Carrillo, M; Salinas, R; Real, G; Belmont, Edgar; González, M. Organización e involucramiento en el trabajo. Un estudio de caso. Entre ciencias: diálogos en la Sociedad del conocimiento, Junio-Sin mes, 61-75, 2013. 
35. Rowold, J. Multifactor Leadership Questionnaire. Psychometric properties of the German translation by Jens Rowold. Redwood, City: Mind Garden, 2005.

36. Lodahl, T. M; Kejner, M. The definition and measurement of job involvement, ]oumal of Applied Psychology, 49, 24-33, 1965.

37. Andújar, C; Martínez, M. El nivel en que se involucran los empleados en el trabajo. Análisis psicométrico de la escala de Lodahl y Kejner mediante las teorías clásica y moderna de la medición, Journal Latinoamericana de Psicología, 28(1), 109134, 1996.

38. Ahmad, R; Solnet, D; Scott, N. Human resource practices system differentiation: A hotel industry study, Journal of Hospitality \& Tourism Management, 17, 84-94, 2010.

39. Gamble, John; Culpepper, Robert; Blubaugh, Meg. ESOPs and Employee Altitudes. The important of empowerment and financial value. Personnel Review, 2002.

40. Zaichkowsky, J.L. Measuring the involvement construct, Journal of Consumer Research 12, 341-352, 1985.

41. González, L; De Elena, J. Medida de la implicación en el trabajo: propiedades psicométricas y estructura factorial del cuestionario «Job lnvolvement», Journal of Psicología del Trabajo y de las Organizaciones, 15(1), 23-44, 1999.

42. Yao, Y; Hu, Q; Yu, H; Grzymala-Busse, J. Rough sets, fussy sets, data mining and, granular computing. Tianjin, China: Springer. ISBN: 978-3-319-25783-9, 2015.

43. López, D; Rivas, E; Gualdron, O. Primary user characterization for cognitive radio wireless networks using a neural system based on deep learning, Journal Artificial Intelligent Review, 52, Pp. 169-195, 2019.

44. Graves, A. Supervised sequence labelling with recurrent neural networks. Heidelberg, Germany: Springer. ISBN: 978-3-64224797-2, 2012

45. Hochreiter, S; Schmidhuber, J. Long short-Term Memory. Journal Neural Computation, 9(8), 1735-1780, 1997.

46. Graves, A; Schmidhuber, J. Framewise phoneme classification with bidirectional LSTM and other neural network architectures. Neural Networks, 18(5-6), 602-610., 2005.

47. Bass, B. Leadership and performance beyond expectations, New York: Free Press, 1985.

48. Escandon, D; Hurtado A. Influencia de los estilos de liderazgo en el desempeño de las empresas exportadoras colombianas, Estudios Gerenciales, 32, 2016.

49. Bycio, P; Hackett, R; Allen, J. Further assessments of Bass's (1985) conceptualization of transactional and transformational leadership, Journal of Applied Psychology, 80, 468-478, 1995.

50. Ahumada, L. Liderazgo y equipos de trabajo: una nueva forma de entender la dinámica organizacional .Ciencias Sociales. [Online], retrieved: http://www.psiucv.cl/wp-content/uploads/2012/10/Liderazgo-y-equipos-de-trabajo.pdf

51. Muhammad K; Peter Kuchinke. Impact of leadership styles on employee's attitude towards their leader and performance: Empirical evidence from Pakistani banks, In Future Business Journal, 2(1), 54-64, https://doi.org/10.1016/j.fbj.2016.05.002, 1996.

52. Barragán, J; Castillo, P; Villalpando, P; Guerra, P. Estrategias de retención de empleados eficientes: Importancia estratégica de la fidelización de los empleados en organizaciones internacionales. Innovaciones de Negocios. México: UANL, 2009. 